\title{
豚肉の塩蔵工程中における物性変化
}

\author{
飯塚俊輔* · 望月義範* ・田代有里* ・ 小川廣男* \\ 水野治夫* ・磯 直道*
}

\section{Physicochemical Properties of Pork Meat during Salting Process}

\author{
Shunsuke IIzUKa*, Yoshinori MochIzUKI*, Yuri Tashiro*, \\ Hiroo OgawA* Haruo Mizuno* and Naomichi Iso* \\ * Department of Food Science and Technology, Tokyo University of \\ Fisheries, 4-5-7 Konan, Minato-ku, Tokyo 108
}

\begin{abstract}
The salt contents of pork meat (pork spare ribs) increased from $0.5 \%$ of raw meat to $3.1 \%$ after one day's salting process at $4 \%(\mathrm{w} / \mathrm{w}) \mathrm{NaCl}$ addition, and then the contents was almost constant. By DSC analysis, it became clear that denaturation of the meat mainly occured on myosin by salting. As the denaturation proceeds, the enthalpy change, $\Delta \mathrm{H}$, (cal/g of meat) of 1.212 rapidly decreased to 0.830 for 3 day's salting and then gradually decreased to 0.736 for 27 day's salting. Elastic modulus, viscosity and rupture strength of the meat increased during salting as a whole. The change of dynamic rigidity of the pork meat pastes by heating exhibited the tendency to decrease at the temperature range from $52^{\circ} \mathrm{C}$ to $58^{\circ} \mathrm{C}$ after 6 day's salting. The result was considered to come from the structure change of the sample due to thermal denaturation of myosin.

(Received Dec. 19, 1994)
\end{abstract}

食肉製品製造における塩蔵法は人類が古くから利用し てきた加工法のひとつである。そうの主たる目的は，従来 は水分活性の低下による食肉の眝蔵性の向上にあった。 しかし, 近年では健康上の理由から低盐洤度製品が主流 となってきており，その目的も塩蔵品特有の風味や食感 を食肉に与えることに移ってきた，すなわち，塩蔵によ り食肉は脱水，成分の濃縮，構成タンパク質の変性等に さらされ，その結果生じる食肉組織構造の変化は食肉の テクスチャーに大いに関係すると考えられる.

我々は, 物性变化は組織の構造変化の反映であるとと らえ,これまで種々の食品の加工中の物性変化を検討し てきたが，その一環として塩蔵加工がある. 我々は先に, 水産塩蔵品としての塩蔵サケについて報告しだ)。本研 究では畜肉塩蔵品として塩葴豚肉をとりあげ，その製造 中の原料肉のレオロジーパラメー夕の変化を加熱変性の 結果と併せて検討した。

\section{実 験 方 法}

\section{1. 試 料}

ベーコンの原料である pork spare ribs（処理後 1 $3^{\circ} \mathrm{C}$ で 5 日間熟成）を用いた. ベーコンの場合，塩葴に用 いられる塩浱度は $2.5 \sim 4.0 \%$ で，原料肉 $1 \mathrm{~kg}$ 当たり $5 \sim$ 7 日間の割合で塭漬けする ${ }^{2)}$. 今回の原料肉はいずれも 約 $3 \mathrm{~kg}$ のブロックであったので，壏蔵条件は $4 \%$ の塩 洤度で, 塩蔵品完成の余裕をみて, 塩蔵日数は 27 日間と した. 原料肉の表面に，肉重量の $4 \%$ の食塩をよくすり 込み容器に入れ，落とし蓋をして上から重石をのせ, $5^{\circ} \mathrm{C}$ で塩蔵した。 その後, 所定の日ごと $(0 \sim 7,10,14,18$, 22，27 日目）に1フフロックづつ取り出し，表面の余分な 塩を流水で洗い流した後, 以後の実験に供した。

\section{2. 塩分，水分および粗タンパク梊の定量}

塩浱度は塩分荟度計（シナール・メディカル， SN-2P 型）により，水分含有量は常圧加熱乾燥法により求めた. 粗タンパク質含量の定量は Kjeldahl 法によった.

\footnotetext{
* 東京水産大学食品生産学科（テ108 東京都港区港南 4-5-7）
} 


\section{3. 応力緩和実駼}

応力緩和害験はテンシプレッサー（タケトモ電機, TTP-50BX 型) によって室温で行った. プランジャーは 直径 $1.8 \mathrm{~cm}$ の円柱型を用い, 皮を取り除いた $3 \mathrm{~cm} \times 3$ $\mathrm{cm}$ 厚さ $1.5 \sim 2.0 \mathrm{~cm}$ の試料に線型性を考虑して, 試料の 破壊が起こらない範囲の $25 \%$ の圧縮変形を与えた．得 られた応力緩和曲線の解析は一般化 Maxwell 模型を想 定した逐次近似法によっだ)

本実験で得られた応力緩和曲線はすべて 4 要素模型で 解析できた。

\section{4. 破断強度測定}

破断強度测定は，円錐角 $45^{\circ}$ （母線長 $32.5 \mathrm{~mm}$, 高さ $30.0 \mathrm{~mm}$ ) の円錐型プランジャーを用いて，応力緩和の 場合と同じテンシプレッサーによって室温で行った. プ ランジャーの進入速度は $2 \mathrm{~mm} / \mathrm{s}$ であった。

\section{5. 功的㓮性率測定}

加熱によるレオロジー特性の変化に関する知見を得る ため，陚料の肉糊について加熱しながら動的剛性率湘定 を行った。 なお，肉糊は，测定中の乾燥を防ぐために塩 蔵肉に重量の $1.0 \%$ の水を加え, 冷却しながらホモジナ イスして得た．测定は㨝れ自由減衰型動的粘弾性測定装 置（レスカ，TPA-10 型）に上り，㨝れ角 $1^{\circ}$ ，昇温速度 $1^{\circ} \mathrm{C} / \mathrm{min}$ で $5 \sim 100^{\circ} \mathrm{C}$ の温度範囲で行った.

\section{6. 示差走査熱量（DSC）㴬定}

DSC 剆定は示差走査熱量計(セイコ一電子工業, SSC560 型)によった. 測定は $5 \sim 120^{\circ} \mathrm{C}$ の範囲で, 昇温速度 $2{ }^{\circ} \mathrm{C} / \mathrm{min}$ で行った，試料側には試料肉約 $11 \mathrm{mg}$ を容量 $15 \mu l$ のアルミニウム製密閉容器に封入したものを用い， レファレンス側には，同試料を同一条件で熱走查した 後, 冷却したものを用いた.

\section{実験結果および考察}

\section{1. 塩分湿度およひ水分含有兵の变化}

Fig. 1 と Fig. 2 に塩葴日数にともなう塩分濃度およ び水分含有量の変化を示す. 塩分濃度は生肉の $0.53 \%$ 加 ら塩蔵 1 日目の $3.13 \%$ に急増し，その後塩蔵 27 日目ま で大きな変化はなかった，一方，魚肉のサケの場合は塩 蔵日数とともにほぼ直線的に増加し，塩蔵 7 日目で $2.9 \%$ ，塭蔵 14 日目で $4.4 \%$ となった 1 。ここの相違は豚肉 ではサケに比へて浸出する水分量が少なく，その速度も 遅いためである。なお，一般に，ベーコンの塩分濃度は およそ3〜4\%であるので, 本実験における塩蔵の程度 は市販製品のそれと同様であると思われる.

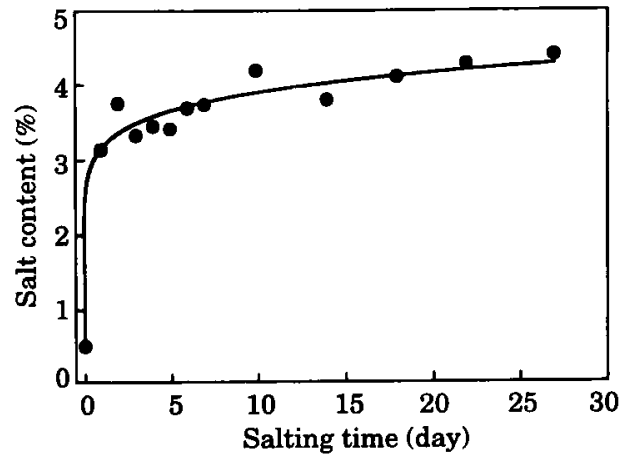

Fig. 1 Change of salt content of meat with salting days

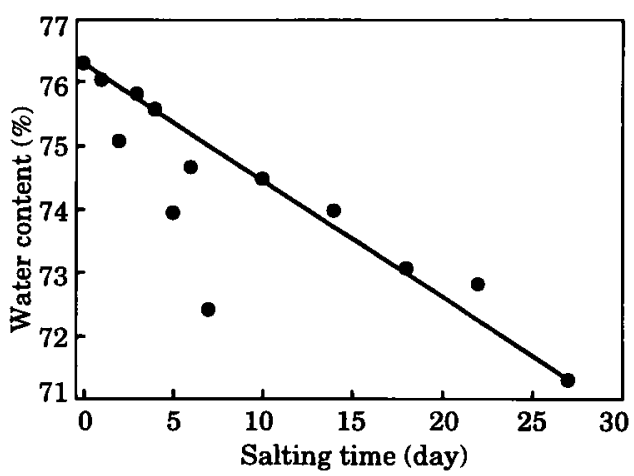

Fig. 2 Change of water content of meat with salting days

2. DSC サーモグラムおよびェンタルピー值の変化

Fig. 3に得られた DSC サーモグラムの例を示す. 塩 蔵前の試料すなわち原料肉では, $54^{\circ} \mathrm{C}, 61^{\circ} \mathrm{C}, 68^{\circ} \mathrm{C}$, お よび $76^{\circ} \mathrm{C}$ 付近に顕著な吸熱ピークが認められた. 牛肉に

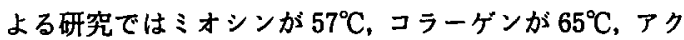
チンが $80^{\circ} \mathrm{C}$ のピークを，また，鬼の脚肉による研究では ミオシンが $60^{\circ} \mathrm{C}$, 筋形質タンパク質が $67^{\circ} \mathrm{C}$, アクチンが $80^{\circ} \mathrm{C}$ にそれぞれピークを示すと報告している4．－一方， BARBUT らの牛肉による研究では，塩化ナトリウム濃度 の増加とともにミォシンの変性温度が低温に移行する結 果を得ている5)。したがって，これらのピークのうち，主 として $54^{\circ} \mathrm{C}$ はミオシンの, $61^{\circ} \mathrm{C}$ はコラーゲンの, $68^{\circ} \mathrm{C}$ は筋形質タンパク質の，そして $76^{\circ} \mathrm{C}$ はアクチンの熱变 性にともなう吸熱ピークと考えることができる。しか

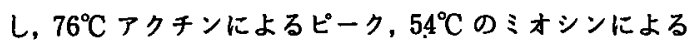
ピークの間の中間領域のピークは, ミオシン, コラーゲ 


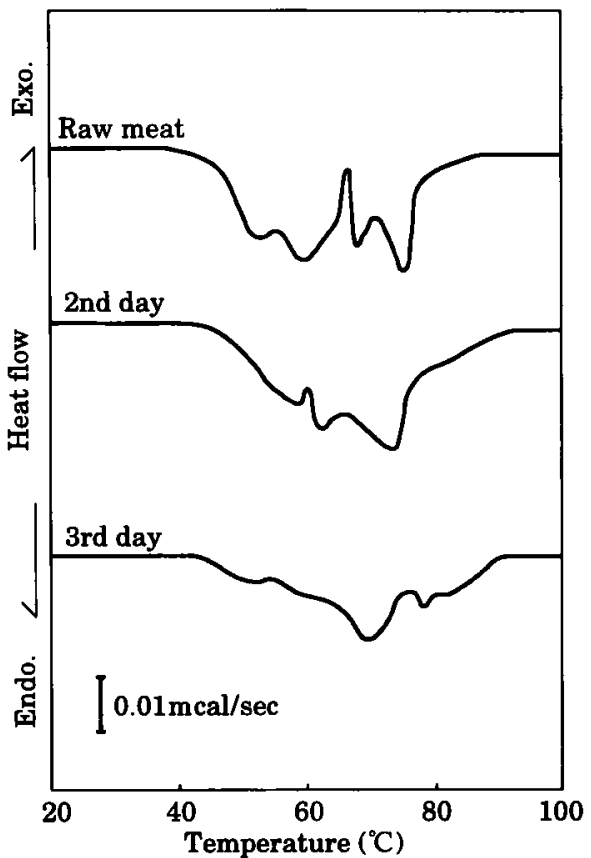

Fig. 3 DSC Thermogram: The upper curve shows the result of raw meat, the middle curve that of 2 day's salting, and the lower curve that of 3 day's salting.

ン, 水溶性タンパク質のピークが重なりあっていると思 われるため，その温度域のピークを正確に個々のタンパ ク質にあてはめることは困難である．2日目には塩濃度 が高まり筋原織維タンパク質の熱安定性が低下している ことは明らかである.それがDSCピークのシフトに なって現れている，しかし，塩は周囲の水を介してタン パク質に影晦を及ぼすと考えられるが，塩葴 2 日目に は，筋原織維の構造変化がわずかなために， $\Delta \mathrm{H}$ は生の 肉のそれとほぼ同じになったものと思われる. $76^{\circ} \mathrm{C}$ の高 温域のピークは, 塩蔵の経過にとすない 2 日目で $71^{\circ} \mathrm{C}$, 3 日目以降では $68^{\circ} \mathrm{C} へ と$ 移行しており，アクチンの熱安 定性が低下したことがかかる。一方，54 ${ }^{\circ} \mathrm{C}$ 付近の低温域 のピークは徐々に小さくなった，従来，アクトミオシン は低温度下で高濃度の塩と反応すると， ミオンンは变性 しないが, アンチンは変性する6) といわれているけれ どあ，本実験結果からミオシンの方がアクチンに較べて 塩の影響による変性を起こしやすいと言うことが出来, このことはサケの場合と同様であった. DSC は試料内 部の諸変化に伴う熱エネルギーの変化を定量的に反映す
る.そこで，塩蔵中の豚肉の変質がタンパク質によるす のか否かを知るために，変性に要する熱エネルギーを見 積った. Fig. 4 にDSCサーモグラムから計算した試料 1 $\mathrm{mg}$ 当たりのエンタルピー変化 $\Delta \mathrm{H}(\mathrm{mcal} / \mathrm{mg})$ の塩蔵 日数依存性を示した。図から明らかなように，生肉試料 の $1.212 \mathrm{mcal} / \mathrm{mg}$ 加 ら塩蔵 2 日目の $1.233 \mathrm{mcal} / \mathrm{mg}$ ま で変化は認められなかったが，3日目に $0.830 \mathrm{mcal} / \mathrm{mg}$ まで急激に低下し，その後は 27 日目の $0.736 \mathrm{mcal} / \mathrm{mg}$ まで大きな変化は認められなかった，一方，粗タンパク 質 $1 \mathrm{mg}$ 当たりの $\Delta \mathrm{H}$ に換算してみると Fig. 5 のように Fig. 4 と同様の減少傾向を示したことからこれらの $\Delta \mathrm{H}$ の減少の主な原因は塩葴日数ととあに増加するイォン強 度の変化によって引き起こされるタンパク質の変性と考 えられる。これらの結果は，魚肉のサケの場合にも見ら

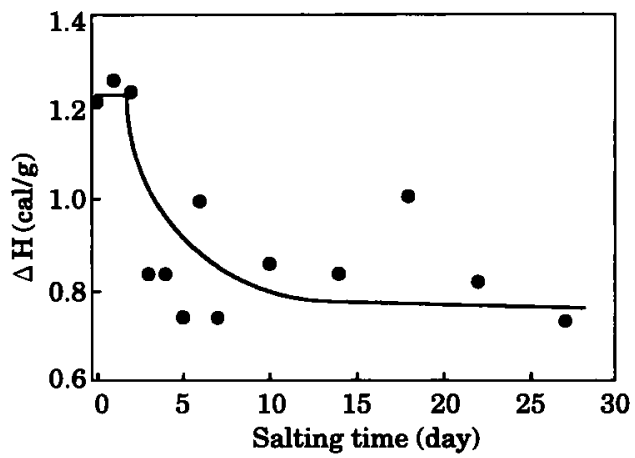

Fig. 4 Salting time dependence of the change of enthalpy

$\Delta \mathrm{H}(\mathrm{cal} / \mathrm{g}$ of meat)

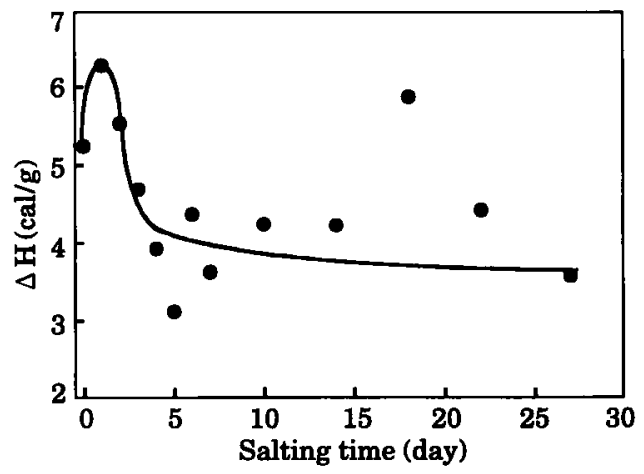

Fig. 5 Salting time dependence of the change of enthalpy

$\Delta \mathrm{H}$ (cal/g of crude protein) 
れた. そして $\Delta \mathrm{H}$ が塩蔵後半ではほぼ一定となり，変性 に要する熱エネルギーが少なくてすむことから，塩の影 響によって試料内のタンパク質は部分的に熱変性を受け た場合と同程度の状態になっていることが示唆された。 塩によるタンパク質の変性機構と熱によるそれとの相違 の解明は今後の課題である.

\section{3. 睡間弾性率, 粘性率およひ破談強度の変化}

塩蔵日数の経過に伴う瞬間弾性率 $\mathrm{E}_{0}$, 第一要素の粘度 $\eta_{1}$ ，および破断強度 F の変化を Fig. 6 に示す．図から明 らかなように，いずれのパラメータも塩藏前から塩蔵 1 日目にかけて増加し，4 日目でいったん減少した後，7日 目に大きく増加した．その後は 10，14，18 日目でやや低 下するものの，22，27 日目では再び高い值へと回復して いる. DSC 测定の結果によれば，塩蔵 1 日目のサーモグ ラフは，塩蔵前のあのと大差がないことからこれらの パラメータの約 4 日目の低下は塩による变性が原因では なく，脱水による見かけの筋肉硬化を上回る試料肉の鮮 度低下にともなう組織の脆弱化によるのであろう。 た，その後の力学的バラメー夕の増加は水分がドリップ として浸出したことによって水分含有量が低下し，その ため試料組織が緻密化したためと考えられる.

\section{4. 動的剛性率の加熱温度徏存性の变化}

塩蔵前, 塩藏 6 日目, および塩葴 14 日目の試料の動的 㓮性率 G'のサーモグラムを Fig. 7 に示す. 6 日目あた りから 52〜 58 ${ }^{\circ} \mathrm{C}$ の高温域に顕著な G' の低下が現れた. この温度域は, AUTIO らの豚肉と牛肉の肉糊おょびそれ らから調製したミオフィブリルサスペンションの動的測 定での G' の低下温度域と一致しており ${ }^{9)}$ これもまた豚 肉での DSC サーモグラムのミオシンの変性温度と一致 している. G’の低下をもたらした原因としてプロテアー

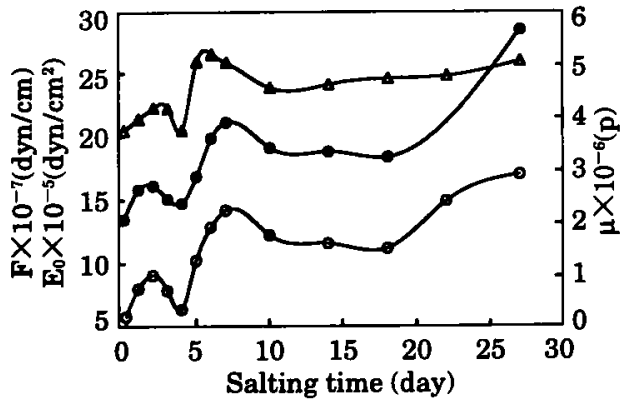

Fig. 6 Changes of instantaneous elastic modulus $(O)$, viscosity of the 1st element (O), and rupture strengh $(\triangle)$ with salting

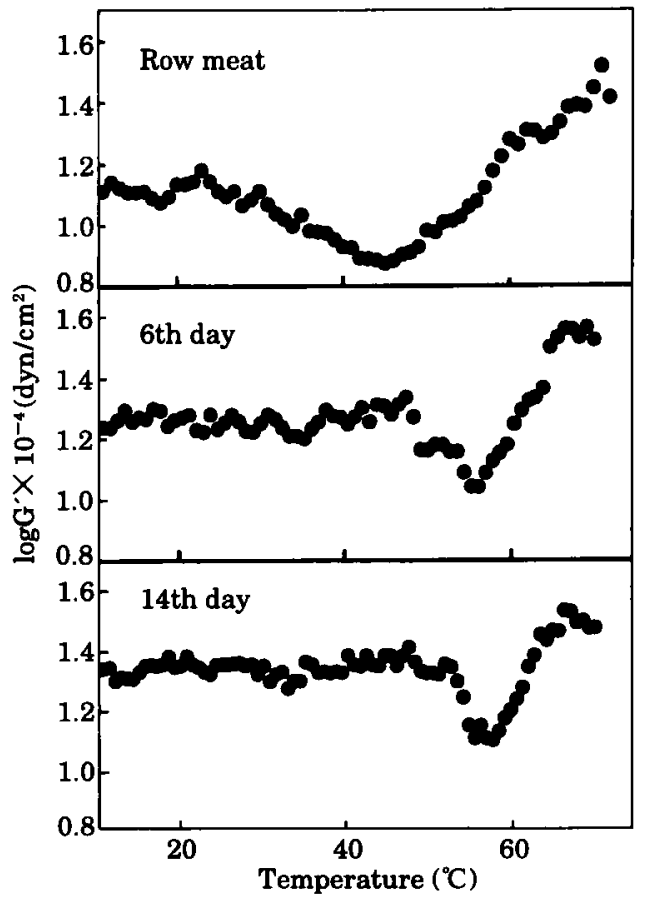

Fig. 7 Heating temperature dependence of dynamic rigidity of meat paste: The upper curve shows the result of unsalting sample, the middle curve that of 6 day's salting, and the lower curve that of 14 day's salting

ゼによる筋原絨維タンパク質の分解が考えられる．魚肉 に関しては，このような高温度域に活性をもつ筋肉プロ テアーゼの報告例 ${ }^{10)}$ はあるが，畜肉に関してはそのよう な酵素の報告はない，したがって，ここでの G’の低下は 塩の影響によって変性したミオシンがさらに熱によって 変性したことによもなう構造変化に起因するすのと考え ている．また， $70^{\circ} \mathrm{C}$ で変性する成分はアクチンと考えて いるが, アクチンに相当する成分の DSC ピークは塩蔵 2 日目から低温側にシフトしている（Fig. 3).しかし $70^{\circ} \mathrm{C}$ 付近の $\mathrm{G}^{\prime}$ が塩蔵日数によって変わらないことか ら，アクチンの熱安定性は低下するもののこの变化はゲ ル構造形成にはほとんど影響していないことが分かる.

要粎

豚肉 (スペアリブ)の塩濃度は，4\% 食塩添加によって 生肉の $0.5 \%$ 加ら塩蔵 1 日後の $3.1 \%$ 人増加し，その後 はほぼ一定となった，示差走查熱量（DSC）測定の結果 
から，塩蔵による肉の変性は主としてミオシンに生じる ことがわかった．変性の進行につれて，エンタルピー变 化 $\Delta \mathrm{H}(\mathrm{mcal} /$ 粗タンバク質 $\mathrm{mg}$ ）は 1.212 から塩蔵 3 日 後の 0.830 まで急減し，その後は塩蔵 27 日後の 0.736 ま で徐々に減少した。試料の弾性率，粘度，破断強度は全 体として，塩蔵中に増加した，䀠肉ペーストの加熱中の 動的剛性率は塩蔵 6 日後は 52 58 ${ }^{\circ} \mathrm{C}$ で減少する傾向を 示した. この結果はミオシンの熱变性による試料の構造 変化のためと考えられる.

本研究に要した経費の一部は財団法人ソルト・サイエ ンス研究盰団からの助成金 (No. 92063) によった. ここ に記し謝意を表する.

$$
\text { 文献 }
$$

1）飯塚俊輔・望月義範・小川廣男・水野治夫・磯
直道 : 日水誌, 61, 71 (1995).

2）佐藤 信 : 食肉の熟成，(光琳，東京), p 601 (1984).

3）磯 直道: 水産食品のテクスチュアー, 丹羽栄二 編, (恒星社厚生閣, 東京), p 9 (1987).

4) WRIGHT, D.J., LEACH I.B. and Willing P.:J. Food Sci., 28, 557 (1977).

5) Barbut S. and Findlay C.F. : J. Food Sci., 56, 180 (1991).

6）若目田篤・新井健一：日水誌，49，645（1983）.

7）若目田篤・新井健一：日水誌，50,635 (1984).

8) IKEUChI, I., TANJI, H., KaKIMOTO, T. and SuZUKI A. : J. Sci. Food Agric., 65, 77 (1994).

9) Autio, K. and Wietsch, F. : J. Food Sci., 55, 1494 (1990).

10）新井健一：水産物加工利用技術研究開発総合報告 書 p. 43 (1985).

（平成 6 年 12 月 19 日受理） 